\title{
Public-private partnership scenario in the health care system of Pakistan
}

\author{
F. Ahmed ${ }^{7}$ and N. Nisar ${ }^{2}$
}

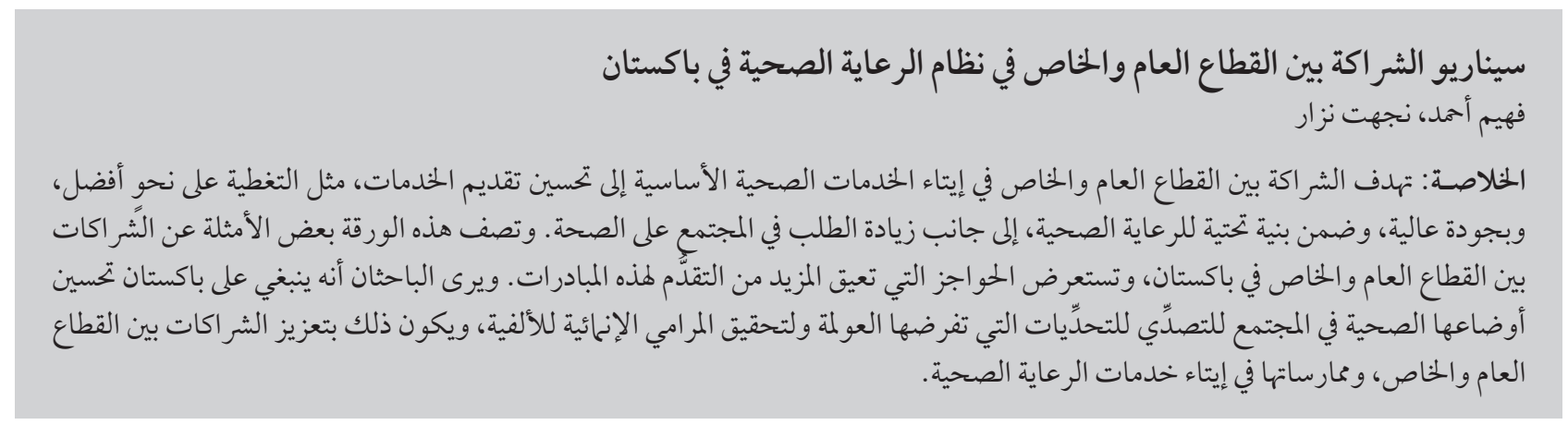

ABSTRACT Public-private partnerships (PPP) in basic health services delivery aim to improve service provision, such as better coverage, quality and infrastructure of health care, as well as raising the demand for health by the community. This paper outlines some examples of public-private partnerships in Pakistan and examines barriers to further development of such initiatives. We argue that to meet the challenges of globalization and achievement of the Millennium Development Goals, Pakistan needs to improve the health status of its society by promoting and practising PPP in providing health care services.

\section{Projet de partenariat public-privé dans le système de santé du Pakistan}

RÉSUMÉ Les partenariats public-privé relatifs à la prestation de services de santé de base visent à améliorer les services fournis, notamment en développant la couverture et la qualité des soins de santé et les infrastructures correspondantes. Ils ont également pour objectif d'accroître la demande de la communauté en termes de santé. Cet article présente brièvement quelques exemples de partenariats public-privé au Pakistan et évalue les obstacles au développement futur de telles initiatives. Nous pensons que, pour relever les défis liés à la mondialisation et la réalisation des objectifs du Millénaire pour le développement, le Pakistan doit améliorer l'état de santé de sa population par la promotion et l'établissement de partenariats public-privé relatifs à la prestation de services de santé. 


\section{Background}

The concept of co-operation between public and private provision of health care was instituted in Pakistan in national health policy in 1960 and started as a model of corporate social responsibility to serve the nation's health needs. Public-private partnerships (PPP), as they are now called, are a health sector reform to create long-term, task-oriented and formal relationships among the public and private sectors in sharing their core competency and resources, including some degree of joint decision-making and innovative interaction to provide sustainable improvements in the provision and enhanced utilization of health care services and also to address emerging health challenges for the benefit of society. A core set of objectives of PPP in basic health services delivery relate to improving service provision, such as coverage, quality and infrastructure, as well as raising the demand for health by the community.

The 1973 Constitution of Pakistan, Article 38(d), guarantees that the State shall provide the basic necessities of life, including the provision of health care. Yet, the apparent priority given national security over human development means that the government seems unable to fulfilits constitutional promise to bring reforms to the health sector of Pakistan. The provision of basic health services in Pakistan is inadequate and is a major obstacle to human development.

Pakistan is facing a double burden of disease. Not only is the country failing to overcome infectious diseases such as poliomyelitis that others have tackled, but it is also facing the challenge of chronic noncommunicable diseases. As far as health indicators are concerned the infant and maternal mortality rates for Pakistan are very high compared even with other developing countries, at around 100 per 1000 live births and 340 per 100000 live births respectively.

\section{Barriers to public- private partnership}

Privatization policies in Pakistan remain largely unexamined and insensitive to the need for basic health services that are accessible, available, affordable and of acceptable quality. This could be due mainly to downsizing of social capital and inadequate financial resources or to disparities in power and lack of trust between the public and private sectors that inhibits collaboration at the policy and operational level in provision of health care in Pakistan. As a result, the health sector in Pakistan is far from developing a consistent form of interaction between the public and private sectors, and suffers from a persisting political polarization along 3 major, intersecting faultlines - bureaucrats, technocrats and the military-that have been evident in Pakistan since the partition of the Indian subcontinent in 1947. This in turn is reflected in a high burden of disease, lack of health care staff, staff absenteeism and poor access to health facilities for patients [1].

According to the Pakistan National Health Policy 2001, primary health care in Pakistan is currently functioning mainly in the private sector through contracting out of health services, which means handing over of un- and underutilized government health facilities, such as basic health units, rural health centres and hospitals to the private sector. This is supposed to provide support for awareness raising and the management of clinical and nonclinical services in the community [2]. This was implemented through a rural support programme.

\section{Pilot programmes}

Pilot programmes were established in 8 districts of Punjab in 2005. About 104 basic health units in one district, Rahim Yar Khan, were handed over to a large nongovernmental organization on a pilot initiative to provide primary health care services to overcome the inability of the health care services delivery system to tackle diseases at basic health units. The World Bank has been a catalyst for such contracting out in Rahim Yar Khan district, which includes providing funds and technical support. However, the Sustainable Development Policy Institute, in cooperation with the University of Birmingham in the United Kingdom, recently conducted a study and found that the PPP results in Rahim Yar Khan district were disappointing, due to lack of a preventive approach, disparities in power and other factors. While the overall utilization of facilities had increased, insufficient numbers of patients were attending basic health units. In this district - where the poorest of the poor are still socially excluded, live in inaccessible areas, lack confidence and information and are unable to pay for services - the services provided remain un-utilized [3]. The government of Pakistan has decided to scale-up the programme to the national level but the benefits of this have not yet become apparent in the general population in terms of improved public health.

\section{Examples of public- private partnership}

The goals of PPP are to create a financially sustainable system, capacity reform and management reform in the public-private sector which may lead to increased health care delivery and utilization, preventing unintended outcomes of private sector growth in health, control health care costs and create improvements in the health status of society, thus facilitating socioeconomic development. In Pakistan there are some examples of successful publicprivate collaborations in health care provision:

- a mobile doctors programme run by a tobacco company since 1980 in the tobacco cultivation areas and at their 
factories as a part of their corporate social responsibility strategy (Pakistan Tobacco Company, 2005);

- the national programmes for malaria, tuberculosis and HIV/AIDS control implemented through a collaboration of government and private health care providers, including the Ministry of Health and the GreenStar Network, the Asia Foundation and HealthNet International; the World Health Organization (WHO), United Nations Development Programme and World Bank support all providers in the services; the Ministry of Finance, Government of Pakistan, subsidizes the insecticide-treated bednets.

- a public sector mother and child hospital in Shikarpur district in Sindh province whose management is handed over to a private practitioner;

- the Health and Nutrition Development Society (HANDS), an NGO in partnership with Sindh government to provide primary health care services at basic health units in Karachi;

- the Aga Khan University Karachi, Pakistan, a private sector partnership with Sindh Government to provide primary health care services in rural and urban slum communities for disease surveillance, vaccines and drug trials;
- Heartfile, an NGO in partnership with government, the International Vaccine Institute (South Korea), WHO, Save the Children and UNICEF, is the supporting agency in a policy development initiative to control noncommunicable diseases;

- a Ministry of Population Welfare and United States Agency for International Development partnership established a social marketing programme from the GreenStar Network in Pakistan to enhance contraceptive use;

- a private company that educates young mothers about healthy baby-care practices and teaches 5-9-year-old children about basic hygiene habits using these activities in the company's marketing strategy (Procter and Gamble) [4].

\section{Challenges}

PPP are considered to be a successful model of health reform in the health sector of other countries [5-7]. So the challenge ahead is for Pakistan to facilitate the implementation of various components of health sector programmes, including establishing norms, tackling morality and accountability issues, building a legislative framework, defining operational strategies, as well as safeguarding the Consumer Protection
Act to safeguard the interest of consumers. The issues we are facing to facilitate implementation of partnerships in providing and encouraging utilization of health care services include a lack of appropriate monitoring and reporting mechanisms, a lack of clarity in policies and low efficiency of the private sector in taking care of the poorest sectors of society.

The research in the field of establishing effectiveness of PPP in providing and raising demand of health care services in the community in Pakistan is limited to rare cases. Furthermore the data to promote health sector reform in Pakistan are unavailable or unpublished. PPP is a multidisciplinary and multi-sectoral approach, which needs significant institutional development, monitoring and evaluations systems.

The government of Pakistan is committed to achieving the Millennium Development Goals for eradicating poverty, providing health and education facilities, ensuring gender equality and combating HIV by 2015 in partnership with the World Health Organization and the World Bank. To meet the challenges of globalization and achieving a prosperous Pakistan in the 21 st century we need to promote and practise PPP in providing health care services to improve the health status of our society.

\section{References}

1. The state of the worlds' children. New York, United Nations Children's Fund, 2001.

2. National Health Policy 2001. The way forward. Agenda for health sector reform. Karachi, Ministry of Health, Government of Pakistan, 2001 (http://www.nacp.gov.pk/introduction/ national_health_policy/NationalHealthPolicy-2001.pdf, accessed 26 May 2010).

3. Siegmann KA, Shaheen N. Joining hands for better health care. SDPI Research and News Bulletin, 2006, 13(4 \& 5):10-15.

4. Siegmann KA, Shaheen N, Shah S. Collaboration between state and non-state providers of basic services in Pakistan. Islamabad, Pakistan, Sustainable Development Policy Institute, 2006.
5. Allen G. The private finance initiative. House of Commons Library Economic Policy and Statistics Section Research Paper, 2001, 01/117.

6. Nayani P, White F, Nanan D. Public-private partnership as a success factor for health systems. Medicine Today, 2006, 4(4):135-142.

7. Nikolic IA, Maikisch H. Public-private partnerships and collaboration in the health sector. An overview with case studies from recent European experience. Health, Nutrition, and Population Family discussion paper. Washington DC, World Bank Human Development Network, 2006. 